tion of the carbides and the size of their particles influence the rate of attack by acids. The texture of the resisting or 'stainless' steels to steam at high temperatures depends on the distribution of the compounds precipitated from the solid during heating. Oxidising agents produce a thin skin on the surface of many metals, and this protects against further action, or fails to protect, according to the texture of the oxide so formed. On a yet finer scale, certain classes of solids containing 'giant molecules' have their chemical properties determined by the shape of those molecules, whether forming thin sheets, fibres, or a loose network. Examples are graphite and other forms of carbon, textile fibres and the zeolites. The study of texture, usually by means of the microscope but also making use of many physical methods, is therefore an essential part of the study of chemically resistant materials.

\section{The Future of Governments}

An address delivered by N. M. Butler at the Parrish Art Museum, Southampton, Long Island, on September 2, attributes the attack on 'liberalism' in the world generally to the very limited extent to which knowledge and power have been linked in official public life, compared with industrial and commercial life. The wide gap between instructed public opinion and Government, and the control of Government by legal formulæ, by passion and by highly organised and effective self-seeking minorities, are largely responsible for the deadlock which threatens many fields of public action. Mr. Butler does not believe that compulsion, whether by a dictator or by a majority, offers any permanent solution of our difficulties. What is required is intellectual and moral discipline to fit mankind for the use of liberty. Dictatorships, no less than democracies, have failed to readjust their policies or the economic life of the peoples concerned to the revolutionary changes in production and intercourse brought about by the application of science. The highest task of liberalism to-day, he claims, is to meet this situation, to show how to end this international anarchy and confusion and to solve these new problems constructively without resort to any form of compulsion. Mr. Butler outlined very broadly the principles of a programme ensuring not only freedom of thought, speech, worship and assembly but also of opportunity to earn a livelihood, and insisted on the importance of preserving individuality in the economic as in other spheres. The whole area of eivilisation requires widening and integrating to relieve the economic conditions from which the attack on liberalism largely arose, and Government, agriculture, industry, transport, commerce and finance require adjusting to the conditions of human life and action existing to-day.

\section{Industry in New Zealand}

Discussing the prospects of industry in New Zealand in an address to the Dunedin Chamber of Commerce on August 21, Lord Bledisloe said that the decline in international commodity exchange and the growing tendency towards economic selfsufficiency must inevitably cause anxiety in countries like New Zealand, Denmark or Argentina, the economic existence of which is conditional upon the export of agricultural produce. New Zealand will have to search for new directions in which her industrial activities may expand, though this as yet can scarcely be in the direction of large-scale industrial production owing to her small population and limited consumptive capacity. First and foremost, efforts should be made to develop the 'tourist industry', which presents great possibilities provided the travel, hotel and similar interests organise and co-ordinate their efforts. Timber plantations, especially of the native beech, should prove a valuable asset, since conditions elsewhere foreshadow a worldwide timber famine within the next half-century. If properly managed and protected from insect and fungoid pests, the forests should afford remunerative employment to a large section of the rural population. of New Zealand's mineral resources, gold is the most important and indeed seems likely to open up the most promising avenue for providing fresh employment. Yet another development of importance would be the revival of the once profitable kauri-gum industry now made possible by new methods of refining low-grade gum. The extraction of oil from the local 'groper' presents distinct possibilities since it is 100 times richer in vitamin $\mathbf{A}$ than the average cod liver oil. Important new industries might be inaugurated for canning meat and for manufacturing casein from surplus milk; the former could readily be marketed in Britain since there is no quota for canned meat as there is for chilled meat.

\section{Preservation of Natural Woodland}

Mr. W. Dallimore read a paper on amenity planting and the preservation of natural woodlands before Section $K$ at the recent meeting of the British Association at Aberdeen. "Amenity planting," $\mathrm{Mr}$. Dallimore said, "and the preservation of natural woodland may be regarded as common ground whereon arboriculture and sylviculture meet." This somewhat dangerous statement is qualified by the subsequent remark that "In many respects sylviculturists are better placed for general amenity supervision than men who are engaged upon arboriculture". Until comparatively recently, the true work of the sylviculturist was but little understood in Great Britain. In fact, by many it was considered to cover all aspects of the forester's work save that of exploitation and extraction. A truer understanding now exists, and Mr. Dallimore is correct in saying that the sylviculturist generally is in a better position to undertake or supervise general amenity work in woodlands and so forth : though this does not mean that he is always as capable as the arboriculturist specialist. The day has arrived, however, in Great Britain when a sharp division should be made in estates budgets, both Government and privately owned, between all planting done for purely amenity purposes, and plantings undertaken for commercial forestry production. Forestry is a definite business 